\title{
Alle over én kam?
}

Alle leger bør beherske medikamentell behandling av pasienter. Allerede før behandlingen blir startet er det gjort mange faglige vurderinger når det gjelder pasientens sykehistorie, eventuell differensialdiagnose, hvilke undersøkelser som skal velges, og om det i det hele tatt er korrekt å starte medikamentellbehandling. God legemiddelbehandling skal bygge på evidensbasert kunnskap, personlige erfaringer med særskilte legemidler og god kjennskap til den enkelte pasient.

Det er stor variasjon blant pasienter når det gjelder alder, komorbiditet og polyfarmasi - dessuten kjønnsbetingede forskjeller. Man burde derfor skreddersy behandlingen til hver enkelt pasient både når det gjelder type legemiddel og dosering. Min erfaring er likevel at det hos en lege, i et legefellesskap eller innenfor et geografisk område oppstår standardiserte behandlingsregimer for forskjellige sykdommer. Med det mener jeg at man behandler pasienter med lik sykdom med det samme legemidlet i samme dose. Dette støttes av statistikk fra reseptregisteret, som viser at det er fylkesvise forskjeller i forskrivningspraksis (1), for eksempel hvilke undergrupper antidepressiver som hyppigst forskrives i de forskjellige fylker. Det trenger ikke være noe i veien for å kjenne noen legemidler bedre enn andre og forskrive disse som førstevalg for de fleste pasientene, men en slik refleksforskrivning kan føre til at man glemmer å ta tilstrekkelig hensyn til alder, kjønn og komorbiditet når legemidler forskrives til nye pasienter. Dette kan innvirke på behandlingseffekt, bivirkninger og interaksjoner med andre legemidler.

I en studie publisert i dette nummer av Tidsskriftet har Kjell Petter Bøgwald og medarbeidere undersøkt kjønns- og aldersforskjeller med tanke på dosering og serumkonsentrasjon av psykofarmaka (2). Et viktig funn i studien er at eldre kvinner har høyere serumkonsentrasjon av antidepressiver enn menn og yngre pasienter av begge kjønn, til tross for at eldre kvinner får forskrevet lavere døgndose av legemidlet. Dette er en tankevekker.

Antidepressiver brukes hyppig i Norge. Ifølge tall fra reseptregisteret brukte ca. $8 \%$ av befolkningen over 20 år antidepressiver i 2010. På norske sykehjem bruker over $35 \%$ av beboerne slike midler (3). At samme dose antidepressiver gir høyere serumkonsentrasjon av legemidlet hos kvinner enn hos menn, og at det tilsvarende er høyere hos eldre enn hos yngre pasienter er kjent fra tidligere studier (4). Årsakene til forskjeller i serumkonsentrasjonen i form av fysiologiske og farmakokinesiske mekanismer burde være kjent for leger. Hva kan grunnen være til at man likevel ikke tar tilstrekkelig hensyn til kunnskapen om at man må bruke lavere døgndoser av legemidler hos kvinner enn hos menn og hos eldre pasienter enn hos yngre pasienter?

Opplysninger om hvilke hensyn man bør ta til pasientens kjønn er ikke lett tilgjengelig. Felleskatalogen har i sin tekst egne punkter for dosering av legemidler til barn og unge $(<18$ år) og til eldre $(>65$ år), men mangler underpunkter om spesielle hensyn ved dosering til kvinner utover forsiktighetsregler for gravide og ammende. Behovet for kjønnsforskjeller i dosering er heller ikke kommunisert fra legemiddelprodusentene. At verken Fellekatalogen eller legemiddelprodusentene kommer med separate anbefalinger om anbefalt doseringsintervall for menn og kvinner, skyldes i hovedsak at det finnes for få studier der man har sett på kjønnsforskjeller i legemiddeldosering. Dette gjelder alle medikamentgrupper og ikke bare psykofarmaka. I Tidsskriftet ble det nylig presentert tall som viste at langt færre kvinner enn menn ble inkludert i behandlingsstudier av kardiovaskulære legemidler (5). Noe av grunnen er at man er forsiktig med å introdusere nye legemidler til kvinner i fertil alder. Eldre pasienter blir ofte ekskludert fra studier, og om sykdommen debuterer i høyere alder hos kvinner enn hos menn, bidrar dette også til at kvinneandelen blant de inkluderte pasientene er lavere enn andelen menn. Resultatet av at færre kvinner inkluderes er at man ikke kan gjøre subgruppeanalyser på kvinner med henblikk på behandlingseffekt, bivirkninger og doseringsintervall, og dermed heller ikke kan gi spesifikke anbefalinger for kvinner og menn.

Hva kan man da støtte seg til for å sikre at pasientene får korrekt legemiddelbehandling? Det kliniske skjønnet er viktig, både for å avgjøre om man skal starte legemiddelbehandling overhodet, hvilken type legemiddel og hvilken dose man skal velge hvis man først starter behandling, og ved evalueringen av behandlingseffekt. Det kliniske skjønnet bør alltid suppleres med standardiserte kartleggingsverktøy eller undersøkelser, ved depresjon for eksempel Montgomery og Åsbergs Depresjonsskala (MADRS) eller Cornells Depresjonsskala $(6,7)$. Serummålinger av legemiddelkonsentrasjon er et nyttig supplement ved manglende behandlingseffekt eller ubehagelige bivirkninger, men etter min mening er ikke rutinemessige serummålinger av alle pasienter behandlet med antidepressiver å anbefale. Den gamle tommelfingerregelen «start low, go slow» for medikamentell behandling av eldre er fortsatt gyldig. Gradvis og langsom opptrapping av et legemiddel kan sikre pasienten mot overdosering. Generelt bør man ta seg tid til å vurdere hver enkelt pasients behov for seg, og utnytte all sin kløkt og all tilgjengelig informasjon ved valg av legemiddel og dose til pasienten. Dette krever mer av legen og er faglig utfordrende, men gjør også hverdagen på kontoret mer spennende og variert. Studien til Bøgwald og medarbeidere er viktig, den minner oss om at ved behandling med legemidler er det ikke tilstrekkelig bare å ha kjennskap til legemidlenes farmakologiske egenskaper. Vi bør også ta hensyn til alders- og kjønnsforskjeller ved dosering.

\section{Sverre Bergh}

sverre.bergh@sykehuset-innlandet.no

Sykehuset Innlandet

Sverre Bergh (f. 1973) er doktorgradskandidat og lege i spesialisering ved Alderspsykiatrisk forskningssenter ved Sykehuset Innlandet. Ingen oppgitte interessekonflikter.

\section{Litteratur}

1. Nasjonalt reseptbasert legemiddelregister. www.reseptregisteret.no (12.1. 2012).

2. Bøgvald KP, Rudberg I, Tanum $L$ et al. Kjønns- og aldersforskjeller ved bruk av psykofarmaka. Tidsskr Nor Legeforen 2012: 132: 288-91.

3. Selbaek G, Kirkevold O, Engedal K. The prevalence of psychiatric symptoms and behavioural disturbances and the use of psychotropic drugs in Norwegian nursing homes. Int J Geriatr Psychiatry 2007; 222: 843-9.

4. Reis M, Aamo T, Spigset 0 et al. Serum concentrations of antidepressant drugs in a naturalistic setting: compilation based on a large therapeutic drug monitoring database. Ther Drug Monit 2009; 31: 42-56.

5. Lochen ML, Kvan E. Kjønnsforskjeller og kardiovaskulære legemidler. Tidsskr Nor Legeforen 2010; 130: 382-4.

6. Montgomery SA, Asberg M. A new depression scale designed to be sensitive to change. Br J Psychiatry 1979; 134: 382-9.

7. Alexopoulos GS, Abrams RC, Young RC et al. Cornell Scale for Depression in Dementia. Biol Psychiatry 1988; 23: 271-84. 